chemicals newly introduced by British manufacturers.

Full notification (from which chemicals supplied to research laboratories will ordinarily be exempt) is elaborate. Manufacturers will be required by means of an acute toxicity test to classify new substances as toxic $\left(L^{2} D_{50}\right.$ less than $200 \mathrm{mg}$ per $\mathrm{kg})$, "very toxic"' $\left(\mathrm{LD}_{50}\right.$ less than 25 per $\mathrm{kg}$ ) or neither, using oral doses in laboratory rats. Ordinarily, the chemical identity of the material will have to be defined, as will the purity of the material and "the nature and the concentration of the main impurities", which may be harder.

For most manufacturers, biological tests will be the most time-consuming. Apart from acute toxicity data (with oral doses in rats, subcutaneous doses in rats or rabbits and inhalation doses in rats), notification requires a 28 -day sub-acute toxicity test, acute toxicity tests with fish and daphnia, tests for skin and eye irritation and of skin sensitization and a mutagenicity test. The regulations empower the Health and Safety Executive to require, on the basis of a preliminary examination of the first set of data (which has to be completed within 45 days) further information including the results of tests for teratogenicity and carcinogenicity.

Exceptions to the strict requirement of notification include the supply of chemicals required for further development and materials supplied in quantities amounting to less than 1 tonne (where chemical identity will usually be sufficient). One possibly attractive let-out is the provision that users of such small quantities may be able to meet the requirements by submitted a sample in a container labelled "CAUTION substance not yet fully tested".

\section{Industrial innovation}

\section{States chip in}

\section{Washington}

Support by the states for technological innovation is becoming fashionable. Echoing a theme launched in Congress and by the federal government three years ago, several states are now beginning to put political force behind legislation intended to stimulate technological innovation in local industry. Many realize that their economic future may depend on their ability to attract and keep high technology companies in competition with rival bidders. Measures are therefore being introduced at the state level comparable with the federal initiatives proposed by President Carter two years ago for stimulating investment in high technology.

Often the new measures include the provision of substantial research funds for state universities to promote research in areas of particular commercial value such as the technology of microcomputers. Many states are also trying to draw their universities closer to the research and training needs of the private sector. Last week, for example, the state assembly of New York passed a package of four bills to promote the growth of high technology industry in the state and to forge closer links between the state government, private industry and local universities.

One of the New York bills would revivify the state's Science and Technology Foundation, originally established by Governor Nelson Rockefeller in 1973 to improve the quality of university research in the state. The new bill, likely to be accepted by the state senate and passed into law, would require the foundation, now virtually defunct, to help small companies obtain federal research grants such as those offered by the National Science Foundation. The bill also provides new incentives for colleges and universities to carry out potentially commercial research, and two members with management experience in high technology companies would be added to the foundation's board. A second bill, concerned specifically with research workers at the State University of New York, would increase the proportion of profits from the successful commercial development of research results that might be kept by a faculty member.

The growing interest of all states in the development of industrial policy has prompted a synposium organized this Saturday (21 February) in Washington by the governor of California, Edmund G. (Gerry) Brown immediately before the annual meeting of the National Governors' Association. Mr Brown has recently proposed a \$22 million "reindustrialization" programme for California, claiming the need to forge a new partnership between government and industry. This demand was the basis of his unsuccessful bid for the Democratic presidential nomination last year - and is expected to emerge again in the 1984 election.

Central to Mr Brown's programme is a proposal to establish a Microelectronics Innovation and Computer Research Operation. This would be based at the Berkeley campus of the University of California and would focus on basic research in microcomputers considered too costly to be carried out by individual companies. The state would allocate $\$ 7.6$ million to the project, $\$ 2.6$ million to be spent by the university and the rest to be matched by grants from private companies, most of which have welcomed the proposal.

Similar plans are being worked up by other states. For example, the Minnesota state legislature is considering a request for substantially increased funds from the Microelectronics and Information Sciences Center at the state university. In North Carolina, whose governor, James D. Hunt, has promised to make the state the centre of the East Coast microelectronics industry, the government agreed last summer to allocate $\$ 1.8$ million to a microelectronics centre in Research
Triangle Park which has already tempted General Electric to commit $\$ 50$ million to an integrated circuit plant nearby.

The Californian initiative is in part defensive. Because of high real estate prices and shortages of technical staff, many states are now sending delegations to Silicon Valley to persuade established semiconductor companies of the virtues of relocating elsewhere. Ohio has already been offering attractive inducements to companies prepared to move their operations, and while Mr Brown will be talking in Washington on Saturday, a delegation from New Orleans will be in California describing the advantages of the Deep South.

David Dickson

\section{Telecommunications \\ Monopoly intact}

Halfway through the committee stage in the House of Commons, the British government has agreed to amend its telecommunications bill in ways that will please British Telecom but are unlikely to reassure telecommunications equipment manufacturers. The amendment will give British Telecom, the new telecommunications authority, the right to be consulted during licensing of equipment for attachment to the public telephone network. Manufacturers, already dismayed at the modest erosion of the public monopoly promised by the original version of the bill, now fear that their freedom to develop new communications technology will be further constrained.

The bill, introduced by Sir Keith Joseph, Secretary of State for Industry, last year, is the British government's watered-down equivalent of the steps taken by the US Federal Communications Commission to stimulate innovation by closer definition of the public monopoly in telephone systems. (Similar moves are under way in West Germany.) The British bill, which would split the mail-handling and telecommunications parts of the Post Office into two separate corporations, would leave British Telecom with total control of the telephone network but shade its monopoly on the supply of equipment.

The procedures in the original version of the bill for ensuring that attachments do not interfere with the operation of the network would take control from one bureaucracy, the Post Office, and give it to another, the Department of Industry. One of the amendments has it that standards will be set by the British Standards Institution in conjunction with British Telecom and the department; licences to manufacture equipment are now to be issued by the department after taking British Telecom's advice. Manufacturers complain that standards will take a long time to set and that British Telecom, potentially a manufacturer in its own right, will retain too much control. These issues are likely to be debated further before the 